\title{
New species of Rhizomyces (Ascomycota, Laboulbeniales) parasitic on African stalk-eyed flies (Diptera, Diopsidae)
}

\author{
Walter ROSSI ${ }^{1, *} \&$ Hans R. FEIJEN ${ }^{2}$ \\ ${ }^{1}$ Sect. Environmental Sciences, Dept of Life, Health and Environmental Sciences, \\ University of L'Aquila, Coppito (AQ), 67100 Italy. \\ ${ }^{2}$ Naturalis Biodiversity Center, P.O. Box 9517, 2300 RA Leiden, The Netherlands. \\ *Corresponding author: valter.rossi@univaq.it \\ 2Email: hans.feijen@naturalis.nl
}

\begin{abstract}
Three new species of Rhizomyces Thaxt., parasitic on African stalk-eyed flies, are described. These are $R$. forcipatus W.Rossi \& Feijen sp. nov., parasitic on various species of Centrioncus Speiser from Ivory Coast, Kenya and Malawi and Teloglabrus Feijen from South Africa; R. ramosus W.Rossi \& Feijen sp. nov., parasitic on Diopsina nitida (Adams, 1903) from Uganda; R. tschirnhausii W.Rossi \& Feijen sp. nov., parasitic on Diopsina africana (Shillito, 1940) from Uganda. All previous records of species of Rhizomyces are presented in tabulated form with updated host names. A key is presented to all species of Rhizomyces. The occurrence of Rhizomyces and other taxa of the Laboulbeniales Lindau in the genera of the Diopsidae Billberg is discussed.
\end{abstract}

Keywords. Afrotropical, Diopsidae, Laboulbeniales, Rhizomyces, taxonomy.

Rossi W. \& Feijen H.R. 2018. New species of Rhizomyces (Ascomycota, Laboulbeniales) parasitic on African stalkeyed flies (Diptera, Diopsidae). European Journal of Taxonomy 474: 1-13. https://doi.org/10.5852/ejt.2018.474

\section{Introduction}

About $10 \%$ of the approximately 2100 described species of Laboulbeniales Lindau, parasitic fungi of arthropods, is associated with the Diptera Linnaeus, 1758. Among the latter, the Diopsidae Billberg, 1820 (stalk-eyed flies) is one of the many families reported as hosts of the Laboulbeniales. The Diopsidae is one of the two families (together with the Chloropidae Rondani, 1856) from which three different genera of the Laboulbeniales have been recorded: Laboulbenia Mont. \& C.P.Robin (3 species), Rhizomyces Thaxt. (10 species) and Stigmatomyces H.Karst. (10 species) (Rossi 1987, 1990a, 1990b). Actually, a diopsid is one of only two insects on which three parasites of three different genera have been found concurrently (Rossi 1982). Moreover, the only fossil species of the Laboulbeniales, Stigmatomyces succini W.Rossi, Kotrba \& Triebel, was found on a diopsid, Prosphyracephala succini (Loew, 1873), in a piece of Baltic amber estimated to be 35 to 55 million years old (Rossi et al. 2005).

Rhizomyces is a relatively small genus with ten species described thus far, all of which are parasitic on Afrotropical Diopsidae (Thaxter 1931; Rossi 1990a). The records of these fungi are not numerous 
Table 1. Literature records for the Rhizomyces Thaxt. species, indicating host and country. If necessary, host names have been updated to bring them in line with actual views on the taxonomy of Diopsidae. Records of unidentified species (such as Rhizomyces sp.) and confusing records were not reported.

\begin{tabular}{|c|c|c|c|}
\hline & Host & Country & Reference \\
\hline $\begin{array}{l}\text { Rhizomyces canzonerii } \\
\text { W.Rossi }\end{array}$ & Diasemopsis cf. silvatica Eggers, 1916 & Sierra Leone & Rossi (1990a) \\
\hline \multirow{3}{*}{ Rhizomyces circinalis Thaxt. } & Diopsis apicalis Dalman, 1817 & Gambia & Thaxter $(1918,1931)$ \\
\hline & Diopsis apicalis Dalman, 1817 & Togo & Feijen (1978) \\
\hline & Diopsis mayae Feijen \& Feijen, 2017 & $\begin{array}{c}\text { Malawi, Mozambique, } \\
\text { Tanzania }\end{array}$ & Feijen \& Feijen (2017) \\
\hline \multirow{3}{*}{ Rhizomyces confusus Thaxt. } & 'Diopsis' & Cameroon & Thaxter (1918) \\
\hline & 'Diopsis' & South Africa & Thaxter (1918) \\
\hline & Chaetodiopsis meigenii (Westwood, 1837) & Sierra Leone & $\begin{array}{l}\text { Rossi \& Leonardi } \\
\text { (2018) }\end{array}$ \\
\hline \multirow[b]{2}{*}{ Rhizomyces cornutus Thaxt. } & Diopsis punctiger Westwood, 1837 & Cameroon & Thaxter $(1918,1931)$ \\
\hline & $\begin{array}{l}\text { Diopsis atricapilla Guérin- } \\
\text { Méneville,1837-1844 }\end{array}$ & DR Congo & Feijen (1978) \\
\hline \multirow{9}{*}{ Rhizomyces crispatus Thaxt. } & 'Diopsis' & South Africa & Thaxter $(1900,1931)$ \\
\hline & $\begin{array}{l}\text { 'Diopsis'; Diasemopsis coniortodes } \\
\text { Speiser, } 1910\end{array}$ & Tanzania & Thaxter $(1908,1931)$ \\
\hline & 'Diopsis' & Togo & Thaxter (1908) \\
\hline & $\begin{array}{l}\text { Diasemopsis interrupta Curran, } 1931 \\
\text { Diasemopsis quadrata Curran, } 1931 \\
\text { Chaetodiopsis meigenii (Westwood, 1837) }\end{array}$ & Cameroon & Thaxter (1931) \\
\hline & Diasemopsis aethiopica (Rondani, 1873) & DR Congo & Thaxter (1931) \\
\hline & Diasemopsis aethiopica (Rondani, 1873) & DR Congo & Collart (1947) \\
\hline & Diasemopsis wolteri Lindner, 1954 & $\begin{array}{l}\text { Central African } \\
\text { Republic }\end{array}$ & Lindner 1962 \\
\hline & $\begin{array}{l}\text { Diasemopsis sp.; Diasemopsis signata } \\
\text { (Dalman, 1817) }\end{array}$ & Sierra Leone & Rossi (1990a) \\
\hline & Diasemopsis aethiopica (Rondani, 1873) & Kenya & Rossi (1990a) \\
\hline \multirow{6}{*}{$\begin{array}{l}\text { Rhizomyces ctenophorus } \\
\text { Thaxt. }\end{array}$} & Diopsis longicornis Macquart, 1835 & Liberia & Thaxter (1896) \\
\hline & Diopsis longicornis Macquart, 1835 & Tanzania & Thaxter $(1896,1908)$ \\
\hline & Diopsis longicornis Macquart, 1835 & Togo & Feijen (1978) \\
\hline & Diopsis longicornis Macquart, 1835 & Sierra Leone & Rossi (1982) \\
\hline & Diopsis apicalis Dalman, 1817 & Sierra Leone & Rossi (1982) \\
\hline & Diopsis mayae Feijen \& Feijen, 2017 & $\begin{array}{c}\text { Malawi, Mozambique, } \\
\text { Tanzania }\end{array}$ & Feijen \& Feijen (2017) \\
\hline Rhizomyces cucullatus Thaxt. & Diopsis diversipes Curran, 1928 & DR Congo & Thaxter (1931) \\
\hline \multirow[t]{2}{*}{ Rhizomyces gibbosus Thaxt. } & Diopsis sp. & Tanzania & Thaxter (1901) \\
\hline & Diasemopsis sp. & Tanzania & Thaxter $(1918,1931)$ \\
\hline \multirow[t]{2}{*}{ Rhizomyces gracilis Thaxt. } & Diasemopsis sp. & Sierra Leone & Rossi (1990a) \\
\hline & Diasemopsis aethiopica (Rondani, 1873) & Kenya & Rossi (1990a) \\
\hline $\begin{array}{l}\text { Rhizomyces kamerunus } \\
\text { Thaxt. }\end{array}$ & Chaetodiopsis meigenii (Westwood, 1837) & Cameroon & Thaxter $(1918,1931)$ \\
\hline
\end{tabular}


and four species are known only from the type series. All previous records of identified species of Rhizomyces are summarized in Table 1. A few of these records need some comments and clarification:

1) The host insects reported by Thaxter $(1918,1931)$ as Diopsis sp. (in quotation marks in Table 1) should be considered as unidentified stalk-eyed flies.

2) The drawing given by Collart (1947: 27, fig. 8) is taken from Thaxter (1908: pl. 52, fig. 19) (as stated by Collart himself in a note on p. 26). This thallus represents what was later described as $R$. confusus Thaxt. However, the thalli in the pertinent slide in Collart's collection preserved in BR belong to the 'true' R. crispatus Thaxt. (André De Kesel pers. comm.).

3) Lindner (1962) reports $R$. gracilis Thaxt. on Diasemopsis wolteri Lindner, 1954 from "French Congo, Fort Crampel", but his detailed drawing (Lindner 1962: 4, fig. 2) clearly shows that the fungus is $R$. crispatus. In the same paper Stigmatomyces sp. is also reported on Diopsis planidorsum Hendel, 1923 and Diopsis erythrocephala Westwood, 1837. Again, the parasite can be safely identified as Stigmatomyces diopsis Thaxt. by means of the drawing (Lindner 1962: 4, fig. 2) and the photograph (Lindner 1962: 5, fig. 3) accompanying the record.

4) The insect hosts of R. ctenophorus Thaxt. from Sierra Leone (Rossi 1982) were reported as Diopsis thoracica Westwood, 1837 and Diopsis tenuipes Westwood, 1837, but were later identified by H.R. Feijen by their senior synonyms as respectively Diopsis longicornis Macquart, 1835 and Diopsis apicalis Dalman, 1817; likewise, host Diopsis thoracica from Togo (Feijen 1978) becomes Diopsis longicornis. This latter species was also erroneously reported as a junior synonym of Diopsis macrophthalma Dalman, 1817 (Feijen 1987).

The name Rhizomyces was given to the genus for the most peculiar feature of the type species: the presence of rhizoids at the base of the thallus penetrating the cuticle of the host insects. Rhizoids are missing in four of the species described later ( $R$. confusus, $R$. crispatus, $R$. gracilis, and $R$. kamerunus Thaxt.).

In the present paper three new species of Rhizomyces occurring on Afrotropical Diopsidae are described. Two of these fungi display quite peculiar characteristics: one (R. ramosus W.Rossi \& Feijen sp. nov.) has a ramified thallus (unique in its genus), the other ( $R$. forcipatus W.Rossi \& Feijen sp. nov.) has a folded basal cell acting like a forceps.

A key to all the species of Rhizomyces, including the new ones, is also given.

\section{Material and methods}

The diopsids bearing Laboulbeniales were collected by means of a sweeping net. The flies were placed in $75-80 \%$ ethyl alcohol in the field for transport to the laboratory, where they were examined with a dissecting microscope. The thalli of the Laboulbeniales were removed from the hosts by means of an entomological pin (\#3) and permanent slides were prepared following the method described by Rossi \& Santamaría (2015), with the exception of a few old slides (HF in RMNH) in which Hoyer's medium was used as mounting medium. Holotypes are deposited in the Botanical Museum of Florence (FI), while the host insects are preserved in Naturalis Biodiversity Center, Leiden (RMNH, formerly Rijksmuseum van Natuurlijke Historie).

Photomicrographs were made with a Jenoptik ProgRes 10 Plus digital camera on a Leica DMR microscope equipped with differential interference contrast optics (DIC). 


\title{
Results
}

\author{
Order Laboulbeniales Lindau \\ Suborder Laboulbeniineae Thaxt. \\ Family Laboulbeniaceae Peyr. \\ Genus Rhizomyces Thaxt., 1896
}

Memoirs of the American Academy of Arts and Sciences 13 (6): 307 (Thaxter 1896).

Type

Rhizomyces ctenophorus Thaxt., Memoirs of the American Academy of Arts and Sciences 13 (6): 308 (Thaxter 1896).

\author{
Rhizomyces forcipatus W.Rossi \& Feijen sp. nov. \\ MycoBank No: MB827885
}

Fig. $1 \mathrm{~A}-\mathrm{C}$

\section{Description}

Basal cell hyaline, subsigmoid, more than twice as long as the maximum width, lying flat on the insect, with the black foot placed laterally and flanked by a depression apparently working as a sucker. Suprabasal cell (cell II) variable in size, shape and color, usually smaller and sometimes darker than the basal. Stalk cell of the appendage (cell III) distinctly smaller and darker than cell II, from which it is separated by a slightly oblique septum. Free appendage usually exceeding the perithecial apex, with the axis consisting of 12-16 almost hyaline cells gradually longer and more slender, each bearing a branch arising from the upper, outer angle; these branches consist of an elongate basal cell bearing distally 2-4 bottle-shaped antheridia with darker necks and a one-celled short, hyaline, slender and erect cell which gives rise laterally to a vertical series of 4-8 very slender branchlets; the latter are dark brown, distinctly curved, with hyaline and enlarged tips. Perithecial stalk-cell (cell VI) long, slender, flexuous and hyaline (or almost so). Basal cell region well distinguished, tinged with very pale brown, concolorous with the perithecial venter, consisting of relatively large, subequal cells with their outer margins bulging outwards. Perithecium almost three times longer than maximum width, the venter very slightly inflated, distinctly enlarged below the brownish tip, which tapers rather abruptly to a subspherical apex. Trichogyne consisting of a club-shaped cell from which arise distally 4-5 spreading branchlets which are curved or sigmoid, sometimes bifurcate, gradually tapering towards the apex. Length from foot to perithecial apex $210-345 \mu \mathrm{m}$; from foot to the apex of the appendage $250-400 \mu \mathrm{m}$; perithecium 70-75 × 25-30 $\mu \mathrm{m}$; antheridia about $20 \mu \mathrm{m}$.

\section{Etymology}

From Latin forceps, referring to the forceps-like shape and function of the basal cell.

\section{Types}

KENYA: Naro Moru river, on Centrioncus decoronotus Feijen, 1983, 20 Jul. 1987, H.R. Feijen leg. (holo-: FI 4100a; iso-: FI 4100b); same data as preceding except different host specimens (para-: FI 4099, FI 4101, FI 4102).

MALAWI: Mt. Soche, on sternites of male Centrioncus jacobae Feijen, 1983, 19 Mar. 1972, H.R. Feijen leg. (para-: FI 4103, RMNH-HF-74); same data as preceding except on wing of the same host 

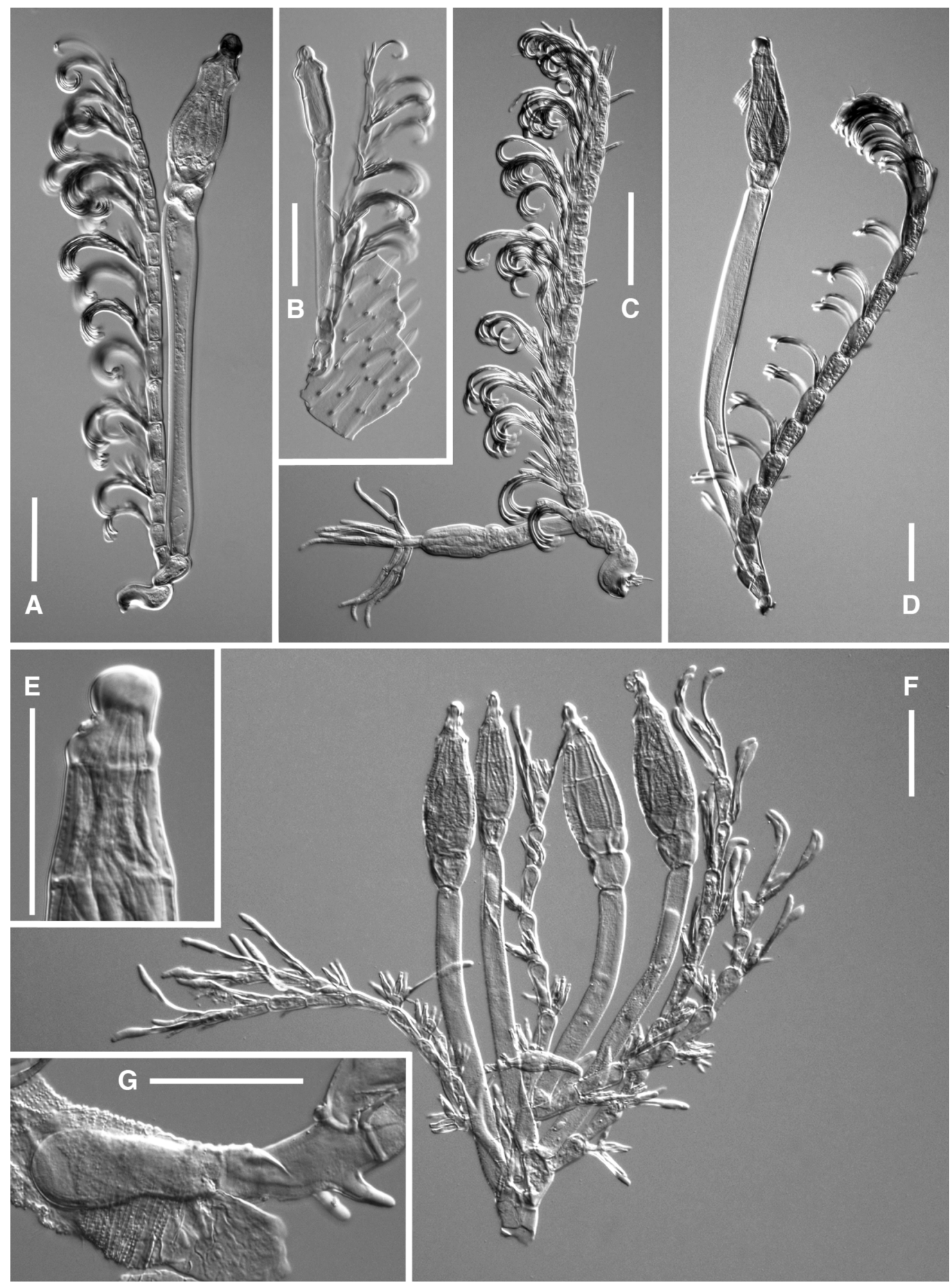

Fig. 1. Photomicrographs of the new species of Rhizomyces Thaxt.: A. R. forcipatus W.Rossi \& Feijen sp. nov. (FI 4100a). B. Thallus of $R$. forcipatus sp. nov. from the wing of Teloglabrus sp. (FI 4125). C. Immature thallus of $R$. forcipatus sp. nov. showing the trichogyne and the basal cell holding firmly a piece of the exoskeleton of the host insect (FI 4099). D. R. tschirnhausii W.Rossi \& Feijen sp. nov. (FI 4091). E. Upper portion of the perithecium of $R$. tschirnhausii sp. nov. (FI 4090). F. R. ramosus W.Rossi \& Feijen sp. nov. (FI 4201a), amid the four mature perithecia, near the base of the stalk cells, it can be seen a fifth very immature perithecium bearing the trichogyne. G. $R$. ramosus sp. nov. (FI 4201a), the pyriform haustorium with remains of the host integument and cell I showing two primordia of new branches. Scale bars: $50 \mu \mathrm{m}$. 
specimen (para-: RMNH-HF-90); Mt. Soche, on sternites of male Centrioncus jacobae, 7 Jan. 1973, H.R. Feijen leg. (para-: RMNH-HF-86, RMNH-HF-87); same data as preceding except on wing of female Centrioncus jacobae (para-: RMNH-HF-88); Mt. Ndirande, on wing of female Centrioncus jacobae, 16 Feb. 1974, H.R. Feijen leg. (para-: RMNH-HF-73).

IVORY COAST: Amanikro, on the wing of a female Centrioncus decellei Feijen, 1983, Sep. 1961 (para-: RMNH-HF-3).

REPUBLIC OF SOUTH AFRICA, Eastern Cape, Hogsback, Tyume Forest, $32.6029^{\circ} \mathrm{S}, 26.9384^{\circ} \mathrm{E}$, 1166 m a.s.1., on Teloglabrus sp., 10 Apr. 2010, A.H. Kirk-Spriggs \& V. de Swart leg. (para-: FI 4125, FI 4126); Western Cape, Buffelsbos forest, $33.9026^{\circ} \mathrm{S}, 23.6388^{\circ} \mathrm{E}, 400 \mathrm{~m}$ a.s.l., on Teloglabrus australis Feijen, 1983, 27 Mar. 2009, A.H. Kirk-Spriggs leg. (para-: FI 4129).

\section{Remarks}

The description is based on the parasites obtained from the sternites of the host insects; thalli growing on the wings are smaller (180-255 $\mu \mathrm{m}$ from foot to perithecial apex: Fig. 1B). The thalli observed on Centrioncus jacobae are paler, more slender and longer on average (up to $550 \mu \mathrm{m}$ from foot to perithecial apex).

Rhizomyces forcipatus sp. nov. is distinguished from all the other species in the same genus by the peculiar shape and function of the basal cell. The latter is turned in, forming a 'forceps' which grasps a fold of the exoskeleton of the host insect (Fig. 1C).

Rhizomyces forcipatus sp. nov. bears a superficial resemblance with $R$. crispatus. However, the latter species has a stockier habitus, a more luxuriant appendage, a distinctly smaller and darker cell III, a darker and subconical tip of the perithecium, and it obviously differs from the new species in the shape of the basal cell.

The presence of this fungus was already reported on various species of Centrioncus Speiser, 1910 and Teloglabrus Feijen, 1983 by Feijen (1983).

Rhizomyces forcipatus sp. nov. is found on several species of the genera Centrioncus and Teloglabrus. This is remarkable, since the species of these genera occur in Afromontane forests and have very limited, allopatric distributions (Feijen 1983). The rate of parasitism came to $17 \%$; however, this figure was lowered by the large Teloglabrus sanorum Feijen, 1983 sample of young flies. In female flies, $R$. forcipatus sp. nov. was only found on the wings. In male hosts, the thalli were found on the wings $(79 \%)$ and on the sterna (30\%). Thalli were most often found on both wings together $(61 \%)$, followed by right wing only (32\%). $90 \%$ of thalli found on the sterna of males flies were on the left hand side (Table 2).

\section{Rhizomyces ramosus W.Rossi \& Feijen sp. nov. MycoBank No: MB827886}

Fig. $1 \mathrm{~F}-\mathrm{G}$

\section{Description}

Basal cell hyaline, usually subcylindrical, distinctly longer than broad, producing more than one suprabasal cell in sequence. The basal cell extends under the integument of the host in a relatively small, ovoid or pear-shaped haustorium. Suprabasal cells irregularly trapezoidal, about as long as the basal, bearing distally the stalk cell of the perithecium paired either with the appendage or with another cell similar in shape and size, from which arise a second perithecium and the appendage. Appendages slender 
Table 2. Prevalence of $R$. forcipatus W.Rossi \& Feijen sp. nov. on host species of Centrioncus Speiser, 1910 and Teloglabrus Feijen, 1983. Given are: totals of hosts examined ( $Q$ and $\lesssim$ ), totals with Rhizomyces Thaxt., infection location. (n. a. = not available).

\begin{tabular}{|c|c|c|c|c|c|c|c|c|}
\hline & \multirow{2}{*}{$\mathrm{n}+$} & \multirow{2}{*}{$\mathrm{n} \delta$} & \multicolumn{2}{|c|}{ infected flies } & \multicolumn{2}{|c|}{ infected $q$} & \multicolumn{2}{|c|}{ infected $\sigma^{\lambda}$} \\
\hline & & & $\mathrm{n} \stackrel{+}{\circ}$ & $\mathrm{n} \delta$ & site & $\mathrm{n}$ & site & $\mathrm{n}$ \\
\hline Centrioncus decellei Feijen, 1983 & 1 & & 1 & & wings & 1 & & \\
\hline Centrioncus decoronotus Feijen, 1983 & 22 & 20 & 2 & 12 & n. a. & & n. a. & \\
\hline Centrioncus jacobae Feijen, 1983 & 33 & 39 & 5 & 13 & wings & 5 & $\begin{array}{l}\text { wings } \\
\text { sterna }\end{array}$ & $\begin{array}{l}11 \\
2\end{array}$ \\
\hline Centrioncus prodiopsis Speiser, 1910 & 2 & 2 & & 1 & & & wings & 1 \\
\hline Teloglabrus australis Feijen, 1983 & 23 & 41 & 2 & 8 & wings & 2 & $\begin{array}{l}\text { wings } \\
\text { sterna }\end{array}$ & $\begin{array}{l}7 \\
2\end{array}$ \\
\hline Teloglabrus curvipes Feijen, 1983 & 2 & 2 & 1 & & wings & 1 & & \\
\hline Teloglabrus duplospinosus Feijen, 1983 & & 4 & & 1 & & & wings & 1 \\
\hline Teloglabrus pelecyformis Feijen, 1983 & 5 & 3 & 1 & 2 & wings & 1 & $\begin{array}{l}\text { wings } \\
\text { sterna }\end{array}$ & 1 \\
\hline Teloglabrus sanorum Feijen, 1983 & 77 & 53 & 3 & 1 & wings & 3 & sterna & 1 \\
\hline Teloglabrus tsitsikamensis Feijen, 1983 & 1 & 4 & & 1 & & & wings & 1 \\
\hline Teloglabrus trituberculatus Feijen, 1983 & 3 & 1 & 1 & 1 & wings & 1 & sterna & 1 \\
\hline Teloglabrus vumbensis Feijen, 1983 & 8 & 4 & 1 & & wings & 1 & & \\
\hline Teloglabrus sp. & 18 & 24 & 3 & 5 & wings & 3 & $\begin{array}{l}\text { wings } \\
\text { sterna }\end{array}$ & $\begin{array}{l}4 \\
3\end{array}$ \\
\hline
\end{tabular}

and flexuous, reaching the tip of the perithecium when erect, the main axis consisting of 8-11 clubshaped cells separated by conspicuous constrictions; the appendages can be either simple or bifurcate from the base, sometimes also bearing 1-3 short lateral ramifications made of 1-4 cells. Each cell of the axis bears close to the base of the following a relatively large cell irregularly shaped, which gives rise to antheridia and sterile branchlets. The antheridia are more numerous in the lower portion of the appendage (up to 5 per cell) and are bottle-shaped with darker necks. The sterile branchlets are gradually longer and more numerous in the upper portion (up to 3 and exceptionally 4 per cell): are slender and chestnut brown, with a hyaline distal portion variably enlarged and variably curved. Perithecial stalkcell (cell VI) very long and slender, of nearly constant diameter, pale amber yellow, with a roughened surface, abruptly distinguished distally from the relatively large and externally prominent basal cell region. Perithecium brownish yellow with the surface roughened by transverse ridges formed by wartlike elevations, broadly pear-shaped, its margins concave distally below a crown of small protuberances which subtend the paler and abruptly tapering tip; the apex is nipple-shaped, subtended on one side by two hemispherical prominences. Up to seven perithecia (six mature and one immature) were seen in a single thallus. Length from the external tegument of the host insect to perithecial apex up to $415 \mu \mathrm{m}$; longest appendages $365 \mu \mathrm{m}$; perithecia 85-102 × 30-40 $\mu \mathrm{m}$; haustorium 20-62 × 15-25 $\mu \mathrm{m}$. 


\section{Etymology}

From the Latin 'ramosus', branched.

\section{Types}

UGANDA: Bushenyi distr., Kazinga Channel SE of Katunguru, $0.1292^{\circ} \mathrm{S}, 30.0525^{\circ} \mathrm{E}, 925 \mathrm{~m}$ a.s.1., on Diopsina nitida (Adams, 1903), 26 Mar. 2012, M. von Tschirnhaus leg. (holo-: FI 4109a; iso-: FI 4109b); same data as preceding except different host specimen (para-: FI 4093).

\section{Remarks}

Rhizomyces ramosus sp. nov. can be distinguished at first glance from all the other species in the same genus by its ramified thallus, but also the shape and the roughened surface of the perithecia are very characteristic.

The presence of this fungus was already reported on Diopsina nitida by Feijen \& Feijen (2013).

\section{Rhizomyces tschirnhausii W.Rossi \& Feijen sp. nov. MycoBank No: MB827887}

Fig. 1D-E

\section{Description}

Basal cell hyaline, relatively small, distinctly wider than tall, with a small black foot placed laterally and flanked by a depression apparently functioning as a sucker. Suprabasal cell (cell II) much larger, yellowish gray, bearing distally the stalk cell of the perithecium (cell VI) paired with the stalk cell of the appendage (cell III). Appendage slender, flexuous, usually sigmoid, seldom exceeding the tip of the perithecium, consisting of 13-17 pale brown cells separated by conspicuous constrictions, the stalk cell subtrapezoidal or irregular, about as long as its maximum width, the others gradually longer, up to twice as long as broad, each bearing, except sometimes the lowest one, a branch arising from the upper, outer angle; these branches consist of a very small basal cell bearing 2-4 slender and relatively small antheridia with darker necks and a one-celled short, hyaline, slender and erect cell that gives rise laterally to a vertical series of slender branchlets; the latter are 2 or 3 in the lower portion of the appendage, up to 5 in the upper portion, black and variably curved, slightly enlarged at the nearly hyaline tips. Stalk-cell of the perithecium very long, erect, subhyaline, nearly uniform. Basal cell region abruptly distinguished, barrel-shaped, orange with a tinge of red, concolorous with the perithecium. The latter about three times longer than the maximum width, its wall cells spirally twisted and marked by transverse striae, the venter slightly inflated, the distal portion tapering gradually and symmetrically to the tip, which is abruptly distinguished, asymmetrical, with one of the lips much larger and hemispherical bulging outwards. Length from foot to perithecial apex $310-710 \mu \mathrm{m}$; from foot to the apex of the appendage 310-540 $\mu \mathrm{m}$; perithecium 100-140 × 35-50 $\mu \mathrm{m}$; antheridia 16-18 $\mu \mathrm{m}$; ascospores about $28 \mu \mathrm{m}$.

\section{Etymology}

Named after Michael von Tschirnhaus, distinguished student of the Diptera and collector of the new species.

\section{Types}

UGANDA: Kasese distr., $17 \mathrm{~km}$ WNW of Kasese, near Nyakalengrja, $0.3444^{\circ} \mathrm{N}, 30.0394^{\circ} \mathrm{E}$, 1630 m a.s.l., on the abdomen of a male of Diopsina africana (Shillito, 1940), 21 Mar. 2012, M. von Tschirnhaus leg. (holo-: FI 4091); Kabarole distr., crater landscape WNW of Fort Portal, $0.6778^{\circ} \mathrm{N}$, 
$30.2250^{\circ}$ E, $1555 \mathrm{~m}$ a.s.1., near the tip of the abdomen of a male of Diopsina africana, 13 Mar. 2012, M. von Tschirnhaus leg. (para-: FI 4090); Kasese distr., 11 km WNW of Kasese, NW above Kilembe village, $0.2217^{\circ} \mathrm{N}, 29.9900^{\circ} \mathrm{E}, 1555 \mathrm{~m}$ a.s.1., on the abdomen of a female of Diopsina africana, M. von Tschirnhaus leg. (para-: FI 4092).

\section{Remarks}

Because of the absence of rhizoids and the slender habitus, $R$. tschirnhausii sp. nov. bears a superficial resemblance with $R$. gracilis, from which it differs for the showy, rounded bulge at the apex of the perithecium, the color of the latter, the stockier and darker cells of the axis of the appendage, and for other minor features. It might be noted that the ascospores are quite small compared with the size of the perithecium: which is a characteristic of all the species in the genus Rhizomyces.

\section{Key to all the Rhizomyces}

It should be noted that $R$. cornutus Thaxt., $R$. cucullatus Thaxt. and $R$. gibbosus Thaxt. are very closely related and the distinguishing characters (in brackets) reported in the key are those given with the original descriptions (Thaxter 1901, 1918, 1931).

1. Thallus not ramified, usually bearing a single perithecium (very rarely 2) ................................... 2

- Thallus ramified, bearing more than one perithecium .............R. ramosus W.Rossi \& Feijen sp. nov.

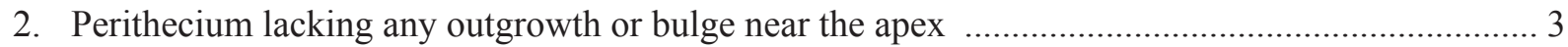

- Perithecium bearing an outgrowth or a bulge near the apex ....................................................... 9

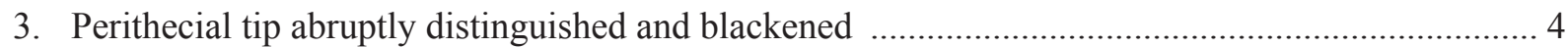

- Perithecial tip not abruptly distinguished and not blackened ......................................................... 5

4. Basal cell subsigmoid, bearing a depression ...................... R. forcipatus W.Rossi \& Feijen sp. nov.

- Basal cell not as above R. crispatus Thaxt.

5. Thallus never reaching $1 \mathrm{~mm}$ in length, not bearing a rounded hausorium 6

- Thallus very slender and elongate, exceeding $1 \mathrm{~mm}$ in length, bearing a rounded hausorium penetrating the exoskeleton of the host

R. canzonerii W.Rossi

6. Thallus not bearing a haustorium penetrating the exoskeleton of the host 7

- Thallus bearing a ramified haustorium penetrating the exoskeleton of the host

R. ctenophorus Thaxt.

7. Perithecium symmetrical or almost so 8

- Perithecium distinctly asymmetrical R. confusus Thaxt.

8. Perithecial stalk-cell at least 3 times longer than the perithecium; appendage and perithecial apex reaching the same height, more or less R. gracilis Thaxt.

- Perithecial stalk-cell about as long as the perithecium; appendage distinctly exceeding in length the perithecial apex

R. kamerunus Thaxt.

9. Perithecium bearing a rounded bulge or a short outgrowth just below the apex 10

- Perithecium bearing a divergent, elongate, finger-like outgrowth just below the apex R. circinalis Thaxt. 
10. Thallus bearing a ramified haustorium penetrating the exoskeleton of the host

- Thallus not bearing a haustorium penetrating the exoskeleton of the host

..R.tschirnhausiiW.Rossi\&Feijensp.nov.

11a.Perithecial outgrowth "relatively narrow and tooth-like"

R. cornutus Thaxt.

11b.Perithecial outgrowth "slightly curved outwards, resembling a peaked hood"

11c.Perithecial outgrowth "broadly rounded and divergent"

R. cucullatus Thaxt.

R. gibbosus Thaxt.

\section{Discussion}

Laboulbeniales are relatively common on African Diopsidae, but are considerably less common on Oriental Diopsidae and are unknown from the extant Holarctic Sphyracephalinae Hennig, 1965. Three reasons can be given for this abundance. Diopsidae live in humid conditions: in rainforests, wet places in savannas and along rivers. Their gregarious behavior is the second factor. Large congregations of thousands of stalk-eyed flies are common and can consist of 10-20 species (Feijen et al. 2017). A third factor is the longevity of the Diopsidae. In Africa, the species are often univoltine with a lifespan of around a year. Due to the shift from earlier to later reproducing flies an overlap occurs between the generations. In, for instance, Diopsis longicornis this overlap occurred in the paddy fields of Malawi to around 2-3 months. Young flies are, of course, without fungi, but during their lifespan the percentage of parasitism increases: in populations of Diopsis longicornis, for example, it can almost reach a 100\%, especially in the males (Feijen 1984). Infection rates increase strongly during the aestivation period, suggesting that transmission through non-sexual physical contact in the aggregations is an important mechanism of spread for Rhizomyces and other Laboulbeniales infecting diopsids. That high host population density, such as aggregations, can promote a transmission of Laboulbeniales was also seen in Hesperomyces virescens Thaxt. infecting the coccinellid beetle Harmonia axyridis (Pallas, 1773) (Riddick \& Schaefer 2005) and in Laboulbenia slackensis Cépède \& F.Picard infecting the carabid beetle Pogonus chalceus (Marsham, 1802) (De Kesel 1993).

In Asia, species of the genera Cyrtodiopsis Frey, 1928, Teleopsis Rondani, 1875 and Megalabops Frey, 1928 are often multivoltine and have a relatively short lifespan. Wilkinson \& Dodson (1997) stated that the average adult ages of two field-caught species of Cyrtodiopsis were estimated to be over 30 days. This is likely to form main reason why Laboulbeniales are relatively uncommon in these oriental genera. The short lifespan appears to form the key factor in this case and not the large number of generations per year. This is different from the situation in Hesperomyces virescens parasitizing Harmonia axyridis. There, Ceryngier \& Twardowska (2013) list the host abundance, multivoltinism with overlapping generations, the high level of promiscuity and the overwintering in mass aggregations as factors facilitating the spread of the parasite. However, in this case the multivoltine hosts may live and reproduce for periods as long as three years.

To date, species of Rhizomyces have been found only on African Diopsidae of the genera Centrioncus Speiser, 1910, Teloglabrus Feijen, 1983, Diasemopsis Rondani, 1875, Chaetodiopsis Séguy, 1955, Diopsis Linnaeus, 1775 and Diopsina Curran, 1928. It appears that these parasites are more common on the stalkless genera of Diopsidae (Centrioncus and Teloglabrus) and on the Diasemopsis genus-group than on the genera Diopsis and Diopsina. In Diopsis, species of Laboulbenia and Stigmatomyces are much more common than those of Rhizomyces; also, Rhizomyces has never been encountered on the thousands of specimens examined of the almost cosmopolitan genus Sphyracephala Say, 1828. The species of Rhizomyces lacking haustoria only occur in Centrioncus, Teloglabrus, Diasemopsis and Chaetodiopsis. These are all more basal branches of the Diopsidae. On the other hand, the parasites of Rhizomyces with ramified haustoria are only found in the more derived genus Diopsis. This could represent a case of coevolution, if it is assumed that the rhizoidal apparatus of the latter parasites represents an apomorphic 
character. The Diasemopsis genus-group and Diopsis separated more than 34 million years ago (F.A.A. Feijen, pers. comm.), so this could also give an indication of the age of the two Rhizomyces groups. Although several of the very common species of Diasemopsis (like Diasemopsis aethiopica (Rondani, 1873)) and species of Diopsis (like Diopsis cruciata Curran, 1934) can be found in large mixed groups for more than half of the year, no horizontal exchange of the parasites of Rhizomyces belonging to the two different groups has ever been observed thus far. A horizontal transfer of Laboulbeniales between different hosts can occur according to Scheloske (1969), but he stressed that "die entsprechenden Parasiten dabei nicht zu eng specialisiert sein dürfen" (i.e., the parasites concerned should not be too specialized). Scheloske discussed the possibility of "Ökologische Specifität bei Laboulbeniales" (ecological specificity) and described a case of ants and a beetle living in the nest of these ants that were both parasitized by the same species of Laboulbenia. Rossi (2011) also discussed the phenomenon of a host switch (or horizontal transfer) in Laboulbeniales. However, it appears that in the case of the two groups of Rhizomyces, these are too specialized to allow for a horizontal transfer between relatively distant taxa of diopsids although these taxa can be found together for long periods in joint aggregations.

\section{Acknowledgments}

We are grateful to Michael von Tschirnhaus (FBUB, Germany) and Ashley H. Kirk-Spriggs (AMGS and BMSA, South Africa) for the opportunity to study the Diopsidae in their collections. The authors wish to thank also S. Santamaría for the pictures with DIC optics. Cobi Feijen assisted with the field and laboratory work on the host Diopsidae.

\section{References}

Ceryngier P. \& Twardowska K. 2013. Harmonia axiridis (Coleoptera: Coccinellidae) as a host of the parasitic fungus Hesperomyces virescens (Ascomycota: Laboulbeniales, Laboulbeniaceae): a case report and short review. European Journal of Entomology 110: 549-557. https://doi.org/10.14411/eje.2013.075

Collart M.A. 1947. Allocution du Président. Bulletin et Annales de la Société Entomologique de Belgique 83: 21-35.

De Kesel A. 1993. Relations between host population density and spore transmission patterns of Laboulbenia slackensis Cépède \& F.Picard (Ascomycetes, Laboulbeniales). Belgian Journal of Botany 126: $155-163$.

Feijen H.R. 1978. Diopsidae (Diptera: Acalyptratae) from Togo and Zaire. Stuttgarter Beiträge zur Naturkunde A 318: 1-25.

Feijen H.R. 1983. Systematics and phylogeny of Centrioncidae, a new afromontane family of Diptera (Schizophora). Zoologische Verhandelingen 202: 3-137.

Feijen H.R. 1984. Studies on the Systematics, Ecology and Economic Importance of the Diopsioinea (Diptera). $\mathrm{PhD}$ thesis, Leiden University. H.M. Oosterhuis, Leiden.

Feijen H.R. 1987. A revision of the Diopsidae (Diptera) described by J.W. Dalman. Entomologica Scandinavica 17: 409-422. https://doi.org/10.1163/187631286X00017

Feijen H.R. \& Feijen C. 2013. A revision of the genus Diopsina Curran (Diptera, Diopsidae) with description of a new species from Guinea-Bissau. Tijdschrift voor Entomologie 156 (2-3): 161-189. https://doi.org/10.1163/22119434-00002029

Feijen H.R. \& Feijen C. 2017. Diopsis mayae sp. n. (Diptera, Diopsidae), a dominant stalk-eyed fly, occurring from South Africa to Saudi Arabia. Tijdschrift voor Entomologie 160 (2): 61-74. 
Feijen H.R., Martin R. \& Feijen C. 2017. The occurrence of Stalk-eyed Flies (Diptera, Diopsidae) in the Arabian Peninsula, with a review of cluster formation in the Diopsidae. Tijdschrift voor Entomologie 160 (2): 75-88.

Lindner E. 1962. Studien an afrikanischen Diopsiden (Dipt.). Stuttgarter Beiträge zur Naturkunde A 94: $1-18$.

Riddick E.W. \& Schaefer P.W. 2005. Occurrence, density, and distribution of parasitic fungus Hesperomyces virescens (Laboulbeniales: Laboulbeniaceae) on multicolored Asian lady beetle (Coleoptera: Coccinellidae). Annals of the Entomological Society of America 98: 615-624. https://doi.org/10.1603/0013-8746(2005)098[0615:ODADOP]2.0.CO;2

Rossi W. 1982. Laboulbeniali della Sierra Leone (Ascomycetes). Accademia Nazionale dei Lincei, Quaderno 255: 9-21.

Rossi W. 1987. New Laboulbeniales (Ascomycetes) parasitic on Diptera. Nova Hedwigia 44 (3-4): $461-464$.

Rossi W. 1990a. New or interesting Laboulbeniales (Ascomycetes) from Sierra Leone. Accademia Nazionale dei Lincei, Quaderno 265: 5-13.

Rossi W. 1990b. New Laboulbeniales (Ascomycetes) parasitic on stalk-eyed flies (Diptera, Diopsidae). Cryptogamic Botany 2: 1-3.

Rossi W. 2011. New Species of Laboulbenia from Ecuador, with evidence for host switch in the Laboulbeniales. Mycologia 103: 184-194. https://doi.org/10.3852/10-117

Rossi W., Kotrba M. \& Triebel D. 2005. A new species of Stigmatomyces from Baltic amber, the first fossil record of Laboulbeniomycetes. Mycological Research 109: 271-274. https://doi.org/10.1017/S0953756204001819

Rossi W. \& Leonardi M. 2018. New species and new records of Laboulbeniales (Ascomycota) from Sierra Leone. Phytotaxa 358: 91-116. https://doi.org/10.11646/phytotaxa.358.2.1

Rossi W. \& Santamaría S. 2015. New species of Aporomyces. Turkish Journal of Botany 39: 354-358. https://doi.org/10.3906/bot-1404-104

Scheloske H.W. 1969. Beiträge zur Biologie, Ökologie und Systematik der Laboulbeniales (Ascomycetes) unter besonderer Berücksichtigung des Parasit-Wirt-Verhältnisses. Parasitologische Schriftenreihe 19: $1-176$.

Thaxter R. 1896. Contribution towards a monograph of the Laboulbeniaceae. Memoirs of the American Academy of Arts and Sciences 12: 187-429.

Thaxter R. 1900. Preliminary diagnoses of new species of Laboulbeniaceae. II. Proceedings of the American Academy of Arts and Sciences 33 (21): 409-450. https://doi.org/10.2307/25129954

Thaxter R. 1901. Preliminary diagnoses of new species of Laboulbeniaceae. III. Proceedings of the American Academy of Arts and Sciences 36 (23): 397-414. https://doi.org/10.2307/20021631

Thaxter R. 1908. Contribution towards a monograph of the Laboulbeniaceae. Part II. Memoirs of the American Academy of Arts and Sciences 13: 217-469. https://doi.org/10.2307/25058090

Thaxter R. 1918. Extra-American dipterophilous Laboulbeniales. Proceedings of the American Academy of Arts and Sciences 53 (9): 697-749. https://doi.org/10.2307/25130007

Thaxter R. 1931. Contribution towards a monograph of the Laboulbeniaceae. Part V. Memoirs of the American Academy of Arts and Sciences 16: 1-435. https://doi.org/10.2307/25058136 
Wilkinson G.S. \& Dodson G.N. 1997. Function and evolution of antlers and eye stalks in flies. In: Choe J. \& Crespi B. (eds) The Evolution of Mating Systems in Insects and Arachnids: 310-328. Cambridge University Press, Cambridge. https://doi.org/10.1017/CBO9780511721946.019

Manuscript received: 12 April 2018

Manuscript accepted: 7 August 2018

Published on: 8 November 2018

Topic editor: Frederik Leliaert

Desk editor: Alejandro Quintanar

Printed versions of all papers are also deposited in the libraries of the institutes that are members of the EJT consortium: Muséum national d'Histoire naturelle, Paris, France, Meise Botanic Garden, Belgium; Royal Museum for Central Africa, Tervuren, Belgium; Natural History Museum, London, United Kingdom; Royal Belgian Institute of Natural Sciences, Brussels, Belgium; Natural History Museum of Denmark, Copenhagen, Denmark; Naturalis Biodiversity Center, Leiden, the Netherlands; Museo Nacional de Ciencias Naturales-CSIC, Madrid, Spain; Real Jardín Botánico de Madrid CSIC, Madrid, Spain; Zoological Research Museum Alexander Koenig, Bonn, Germany. 